\title{
Patterns of Differentiation of Students' Competencies: A Comparative Study
}

\section{Ewa Głowacka, Małgorzata Kisilowska, and Magdalena Paul}

\begin{abstract}
The study focuses on the issue of how much information competencies are universal in the globalized, internet-connected world, and/or to what extent their perception depends on local conditions and individual needs. The aim of the project is threefold. First, it offers a comparative analysis of the information literacy skills of Polish and Spanish students, regarding both their self-assessment and belief in the importance of information literacy. Second, it focuses on differences and unique IL needs of students of courses rooted in social sciences and/or humanities. And third, due to these differences, it discusses the role of academic librarians in profiled IL training, integrated with the specific courses. Quantitative methodology was applied. The comparative study covered subgroups of humanities and social science students from Poland and Spain. Competencies in information searching, processing, evaluation, and communication/dissemination were taken into account. The results indicate some common ways of perception of valuing information competencies and major differences in assessment of IL self-efficacy. Students' reluctance to visit libraries is another argument to enhance profiled IL training being realized in close cooperation of academic librarians and the faculty.
\end{abstract}

\section{Introduction}

In the information society, the knowledge, skills, and attitudes associated with understanding and using information are crucial. They affect educational achievements and, as a result of this, an individual's position on the labor market, participation in society, and quality of life. In this context, it is worth looking at the competencies of young people, many of whom already belong to the generation of digital natives. What is also important is to observe the acquiring of these competencies and identifying barriers in this process. In this article, we take up this topic on the example of students of humanities and social sciences of selected universities in Poland and Spain.

In the following paragraphs, we discuss the specifics of information literacy (IL) of the students, their beliefs on the importance of particular competencies and self-assessment, refer-

\footnotetext{
* Ewa Głowacka is affiliated with the Institute of Information and Communication Research at Nicolaus Copernicus University in Toruń, Poland; email: egt@umk.pl. Małgorzata Kisilowska and Magdalena Paul are members of the Faculty of Journalism, Information and Book Studies, University of Warsaw, Poland; email: mdkisilo@ uw.edu.pl,m.paul@uw.edu.pl. (2020 Ewa Głowacka, Małgorzata Kisilowska, and Magdalena Paul, AttributionNonCommercial (https://creativecommons.org/licenses/by-nc/4.0/) CC BY-NC.
} 
ring to the results of Spanish and Polish projects, including respondents from social sciences and humanities. ${ }^{1}$ The aim of the project was threefold:

- A1: the comparative analysis of information literacy skills of Polish and Spanish students, regarding both their self-assessment and belief in the importance of information literacy;

- A2: to analyze similarities, differences, and unique information literacy needs of students of social sciences and humanities;

- A3: to discuss the potential of profiled IL training offered in close cooperation between academic librarians and the faculty, and integrated with the specific courses.

We hypothesized that the image of Polish students' beliefs and self-assessment regarding information literacy will be quite similar to the Spanish results. Verification of this hypothesis, as well as the general results of the project, led us to another research question, which is discussed in detail in the following sections. The question concerns further exploration of IL needs that were revealed in the study, and the potential adaptation of information literacy training to specific learning outcomes to be achieved by the graduates of particular courses.

Significant differences among students in different courses of study (history, journalism, library and information sciences) indicate consideration of training derived from the IL education needs depending on the course, and particularly the set of competencies to be achieved by its graduates.

\section{Differentiation of Information Literacy Levels: Previous Research Findings}

To be information literate, a person must be able to recognize when information is needed and have the ability to locate, evaluate, and use the needed information effectively - this statement of Presidential Committee on Information Literacy is often quoted as most relevant, most recognized, and the most frequently cited definition of IL. ${ }^{2}$ There are numerous conceptions, standards, and frameworks surrounding the IL subject. We would like to draw attention to its important aspect, often overlooked, but important for the subject of this study. Namely, there are two interconnected aspects of information-external and internal, derived from more subjective reality. In an attempt to explore the internal aspect of the information, we used an IL-HUMASS survey. It is described as a three-way internal lens comprising the dimensions of motivation, self-efficacy, and preferred source of learning, and provides an internal vision of the IL situation among the surveyed population. ${ }^{3}$

Self-efficacy is one of the major concepts of Albert Banduras' social learning theory ${ }^{4}$ $\left(\right.$ renamed as social cognitive theory ${ }^{5}$ ). If we define efficacy as a power to produce the effect, then self-efficacy or perceived self-efficacy is an awareness of one's ability to be effective and to control actions. Self-efficacy is not concerned with specific skills but rather with the judgments of what a person can do with those skills. ${ }^{6}$ Self-efficacy is a highly contextual concept, related to a given situation in a certain field. Therefore, its measurement scales should be also customized to the studied domain. ${ }^{7}$

The level and scope of information literacy among students of different disciplines have been researched in different projects and compared among countries and universities. Considering the relation of these trainings to the students' perceptions of their skills, the types of researches to be mentioned here are obviously evaluations of education activities. They include, for instance, pre/post tests showing their effectiveness. ${ }^{8}$ Most of them prove to be an improvement in students' information literacy skills as a result. ${ }^{9}$ 
Information literacy of the LIS students was analyzed in the international interdisciplinary research of the IL and students' behavior conducted in 18 countries, with particular emphasis on the differentiating characteristics in relation to a given country. ${ }^{10}$ The respondents revealed IL attitudes and behaviors similar to the others. They considered information retrieval and assessment as quite an easy task (however, relying mostly on search engines), and starting research inquiries (defining precise topic and scope) as more difficult. ${ }^{11}$ Differences between countries were also reported, for example, concerning the usage of Wikipedia (more intense among students from France, Bulgaria, Turkey, Portugal, and Poland) or research databases (more popular in the United States, Australia, and Singapore). Respondents from Turkey, Bulgaria, Croatia, Lithuania, Singapore, France, and Portugal found evaluating web sources more difficult than the others. ${ }^{12}$ These dissimilarities become an evident incentive to the comparative analysis of information competencies in two dimensions: among students of different courses and countries.

Effective IL instructions should be dedicated to the scope of the discipline being studied. This recommendation has been often repeated in literature ${ }^{13}$ and realized mostly as training focused on information resources and searching strategies adapted to research and/or education needs of students and lecturers of specific courses. Jiři Kratochvil ${ }^{14}$ presented the results of the medical students' survey concerning their perception of e-learning IL course and mentioned (among others) adaptation of curriculum to future needs of the respondents, depending on the discipline being studied.

Surveys concerning students' self-efficacy in terms of their information literacy are helpful in determining the content of IL curricula. Khalid Mahmood ${ }^{15}$ confirmed that students felt more competent in their skills related to the use of ICT than information retrieval skills, and-interestingly - a statistically significant relationship between the IL level and the field of study, involvement rate, English language command, and access to a home-based computer. Moreover, students' self-assessment is usually higher than their actual skills. ${ }^{16}$ Self-efficacy and evaluation of actual skills are the main focuses of the projects concerning students' information literacy.

\section{Students' Self-efficacy}

Young people highly evaluate their online skills, especially the ones concerning searching. ${ }^{17}$ However, such high self-efficacy is hardly justified, since, in fact, they are often not able to find the required information. Actually, they overestimate their knowledge and skills, confusing information literacy with internet navigation, particularly if they consider a task easy to perform. ${ }^{18}$ Such an opinion is also confirmed by a study on MA business students - the comparison of their perceptions of their information literacy with the results of the skill tests reveals some discrepancies between the actual (low) and perceived (high) level of their skills. ${ }^{19}$ Generally, the students assess their ICT and the internet searching skills higher than their information retrieval skills, use of digital libraries, library catalogs, and advanced search. The studies showed no statistically significant relationship between IL and gender or social background. ${ }^{20}$

It is very interesting to look at the competencies of students in the field of library and information studies. The LIS students rate their information literacy high, as confirmed by the surveys in Turkey, ${ }^{21}$ Australia, ${ }^{22}$ and Israel. ${ }^{23}$ The Israeli survey, related to the self-efficacy of the information retrieval behavior, showed the statistical association of the IL with age 
and the study cycle. The older group reported an impact of experience, emotional state, and friends feedback. In turn, the research of American students, librarians, and teachers on information literacy development during the first year of studies shows some differences between students according to the learning methods. Students who were more engaged in the education process, with individual assignments to be realized, assess the efficacy, importance, and influence of IL training on their own competencies higher than the students who were not engaged. They rate their skills higher, and the importance of education influence lower, than the librarians and teachers. ${ }^{24}$ This result is in line with the findings of previous projects, like one of the first-year college students ${ }^{25}$ and the systematic review of 53 English language studies that assessed and compared people's self-reported and demonstrated information literacy (IL) skills. In 34 studies (64\%), the evidence clearly showed that the participants overestimated their self-reported IL skills compared to their actual skills. ${ }^{26}$

\section{The Actual Level of Students' Information Literacy}

Apart from the self-efficacy research, results also show the actual low information literacy of students. The project conducted in 2010 in 25 American universities indicates that, in terms of their studies, the respondents limit their search to manuals, Google, and the most popular databases. They usually employ search engines, Wikipedia, and friends' assistance to find everyday information. Regarding information quality evaluation, the students mainly verify their origin (internet or library). ${ }^{27}$ Similar conclusions stem from other studies. ${ }^{28}$ Interestingly, if the respondents manage to find some information, both the employed strategy and the sources become their searching routine. Moreover, they rely on internet rankings more than on their own evaluation of the search results. ${ }^{29}$

It seems that cooperation of academic librarians and lecturers would be an optimal way to attempt to strengthen students' information competencies. It includes librarians' participation in courses (syllabuses, assignments, final tests, and so on) design and actual teaching, ${ }^{30}$ and online courses as well, ${ }^{31}$ focused on information literacy and research skills. Cooperation of the librarians and the faculty enables customization of the IL content and teaching methods to the specific needs of a course being studied, as well as future work requirements. It has been observed in different types of sciences, including, for example, music, ${ }^{32}$ engineering, ${ }^{33}$ pedagogical studies, ${ }^{34}$ and sciences and technology. ${ }^{35}$ Other examples have been discussed in literature reviews on this topic. ${ }^{36}$ Additionally, it not only improves students' skills but also presents in a more attractive and practical way the role of information skills, as well as libraries and other information units in research and professional activities. Educational projects of this kind conclude with significant success; that is to say that the students' assignments demonstrate substantial improvement of their information and research skills. ${ }^{37}$ The lecturers appreciate this kind of cooperation, observing actual librarians' contributions and unique knowledge. ${ }^{38}$

\section{Information Literacy Education at Polish and Spanish Universities}

Fundamental similarities come from the fact that both countries are members of the European Higher Education Area (EHEA), offer studies in BA+MA system, and participate in the student exchange system. What is more important, though, is that EHEA incorporates digital competency, (regarding searching, gathering, processing, and evaluating information and using it critically), among other key competencies of lifelong learning. 
In both countries, traditional information literacy teaching was provided in two formsthrough library training and as part of classes at the university. Since the implementation of the Bologna system in Spain, it has been noted that attempts have been made to increase the integration of information literacy education within the framework of the courses (programme ALFIN). The role of the libraries has increased as courses provided by Spanish university libraries are often acknowledged with ECTS scores and/or librarians identify subjects in which IL issues are approached for interdisciplinary work with teachers. ${ }^{39}$

Against this background, Poland is still at an earlier stage of advancement. Despite the efforts of mainly academic librarians, there has been no single program of library training based on the literary information concept. The libraries of medical schools that have developed the standards and the concept of education called MedLibTrain are a notable exception. There are also no initiatives from representatives of the administration responsible for the entire education system. Higher education standards in the field of information education refer mainly to technical skills. ${ }^{40}$

Furthermore, the level of digital skills (that is, skills connected with using computer and internet), as well as communicating and problem-solving using these technologies, ${ }^{41}$ seems to be comparable among young people in both countries. It is also quite similar to the distribution of the variable for the European Union, as shown in the graph below. In this context, it is important to scratch beneath the surface and try to find if and in what way perception of young people's competencies in two analyzed countries is similar as well.

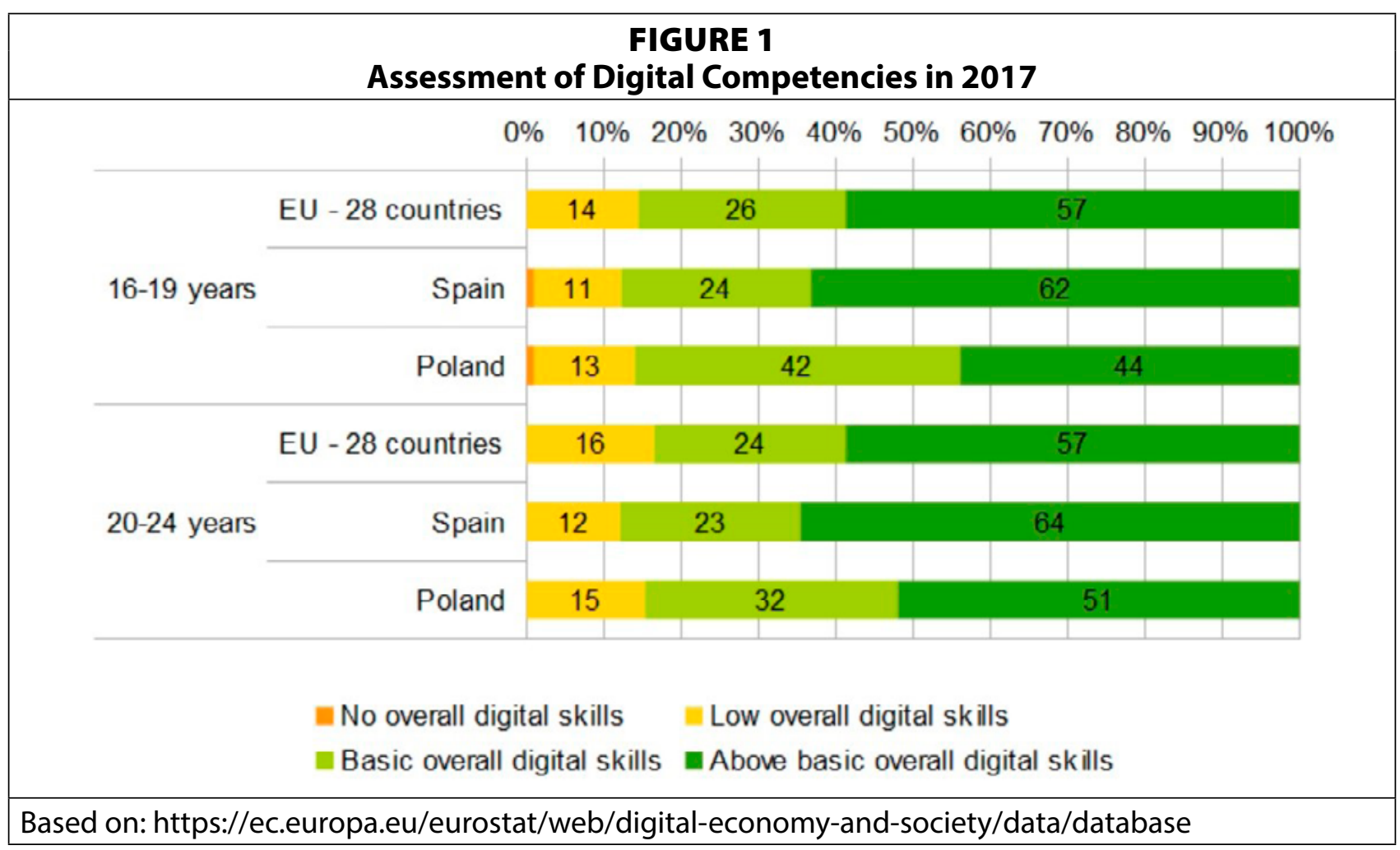

\section{Research Design}

The original Polish project ${ }^{42}$ referred to previous Spanish studies ${ }^{43}$ of information literacy in selected social sciences and humanities. As the latter, it was based on the IL-HUMASS ${ }^{44}$ questionnaire to survey beliefs of importance (BIM) and self-efficacy (SE). The IL skills were 
grouped into four categories: information searching, retrieval, evaluation, and communication. We further compared Polish and Spanish results to find potential similarities or differences in the attitudes and beliefs of the respondents.

The methodology of research conducted in Spain was precisely described in the following works of Pinto and Pasqual. ${ }^{45}$ Polish research was conducted between May and July 2017 at two Polish universities: the University of Warsaw (UW) and the Nicolaus Copernicus University in Torun (NCU). It targeted students from three fields of study-history, journalism, and library and information science-and included three levels of study (see table 1). An auditorium questionnaire (in other words, questionnaire to be filled out by the respondent in writing) was conducted on randomly selected days, on randomly chosen classes, and during breaks between them (therefore, students had approximately 15 minutes or more to complete the survey), among all students available during the probe and willing to take part. The researcher's role was to hand out and collect questionnaires, present the purpose of the research, and explain any inaccuracies. The students' task was to determine how the competency is important to them, how they assess their skills, and how they achieved it - for a set of 26 competencies. Students were instructed to take their time. They were also informed that the survey was anonymous so they could (and were encouraged to) give honest answers, to avoid the bias of perceived researcher expectations. To increase their motivation, we reported that the research was conducted at various universities and in many units, and the answer of each person was important to give the complete picture of information competencies among students.

At NCU the study was successfully completed among 51 percent of BA and 36 percent of MA students of LIS, 25 percent of BA and 55 percent of MA history students, and 73 percent of BA journalism students (there are no MA studies in this discipline at NCU). At UW these percentages were distributed as follows: 17 percent of both BA and MA LIS students, 13 percent of BA and 5 percent of MA history students, and 5 percent of BA and 4 percent of MA journalism students. In general, 47 percent of the population (out of 283 students in total) at NCU, and 7 percent at UW (out of 2,675) were surveyed. Therefore, the sample was not representative; however, it is a common issue in case of auditorium questionnaires, and a quite sufficient part of the population was covered. For example, in the Spanish surveys mentioned above, the percentages of LIS undergraduates from the second and fourth year were similar $(9 \%)$ and the percentages in the third and fifth year were slightly higher (13\%). The highest participation was from first-course students (34.7\%). Graduates accounted for 18.6 percent. ${ }^{46}$ In the survey of social sciences students of five Spanish universities, the sampling amounted to approximately 20 percent of the surveyed population, and the one concerning history students included 252 validated cases (17.8\% of the population) from three universities. ${ }^{47}$

At NCU no PhD students were available at the time of the survey. At UW two PhD students of journalism and one of history took part in the study. Because the PhD students group is relatively small in comparison to other study cycles, and only a few of them were reached, they were included in the graduate students subgroup in the following analysis, assuming that their competencies and expertise may be quite similar.

A detailed structure of the research sample is presented in table 1.

A total of 216 women and 103 men were surveyed. Twenty-one respondents chose not to disclose their gender in the survey. The surveyed LIS students ranged between the ages of 18 and 54 . 


\begin{tabular}{|l|c|c|c|c|c|c|c|c|}
\hline \multicolumn{7}{|c|}{ TABLE 1 } \\
Research Sample - NCU and UW Students \\
\hline \multicolumn{7}{|c|}{ Study Cycle } \\
\hline \multirow{2}{*}{ Field of Study } & \multicolumn{2}{|c|}{ BA } & \multicolumn{2}{c|}{ MA } & \multicolumn{2}{c|}{ Ph.D. } & \multicolumn{2}{c|}{ No Data } \\
\cline { 2 - 10 } & NCU & UW & NCU & UW & NCU & UW & NCU & UW \\
\hline Library And Information Science & 41 & 28 & 14 & 14 & 0 & 0 & 1 & 2 \\
\hline Journalism & 29 & 64 & 0 & 23 & 0 & 2 & 0 & 13 \\
\hline History & 15 & 48 & 35 & 7 & 0 & 1 & 0 & 2 \\
\hline No Data & 0 & 0 & 0 & 0 & 0 & 0 & 1 & 0 \\
\hline TOTAL & $\mathbf{8 5}$ & $\mathbf{1 4 0}$ & $\mathbf{4 9}$ & $\mathbf{4 4}$ & $\mathbf{0}$ & $\mathbf{3}$ & $\mathbf{2}$ & 17 \\
\hline
\end{tabular}

\section{Summary of Results}

The survey, based on the IL-HUMASS questionnaire, revealed differences in Polish students' self-efficacy and beliefs in the importance of information literacy in comparison to the attitudes of Spanish students, depending on the discipline studied. These results are interesting and important in several aspects. First, they reveal attitudes of students of different courses. Those of social sciences display both common and different attitudes concerning the importance of selected information skills. The former may come from their current life stage (studies, age, the common experience of living in the information society), and refer mostly to searching and using information, writing texts, and communication. The latter potentially results from the field of education: history students focus on slightly different skills than those from other disciplines, and LIS students are better oriented in the role of ICT skills and information searching.

Second, the students - rightly or wrongly - present high self-efficacy regarding selected categories of competencies. All the respondents feel quite skilled in internet searching; however, as some studies suggest, ${ }^{48}$ and lecturing experiences often confirm, these beliefs can be at least partially misleading. They are usually based on experiences with the Google search engine, limited only to simple, not advanced, searching. These results would require in-depth research of the students' self-assessment in terms of the knowledge and usage of multisearch engines, deep web and specialist search engines, or subject gateways.

Third, comparisons of the results of both countries show a relatively large similarity in attitudes, self-efficacy, and sources of competencies. However, one might notice a few differences. These issues are discussed in detail in the next part, but general conclusions can be summarized by the following: ${ }^{49}$

1. Students' belief in the importance of selected IL skills is mostly higher than their self-efficacy.

2. Depending on the course students attend, they feel more competent in communication, searching, or information evaluation, but all of them assess their information processing skills as being less developed.

3. Gender does not differentiate the study group concerning the assessment of the importance and self-efficacy of IL. Students gain information skills mostly independently or in classes, but they do not visit libraries to get or improve their knowledge.

Due to differences in the studied populations, and a lack of control of certain variables (such as age), we conducted comparisons with caution. Because we did not have access to the Pinto and Pascual datasets, we compared the more general dependencies and conclusions on 
hypotheses obtained in individual studies. Statements regarding similarities or differences are therefore based on general results, not on statistical tests carried out on two samples (that is, Spanish and Polish students).

\section{Patterns of Differentiation of Students' Competencies}

\section{Field of Study}

According to students' belief in importance, we can see quite significant and steady patterns of competencies assessment in subgroups distinguished by the field of study. Both information science and journalism students from Poland and Spain tend to assess communication as the most important dimension of all, followed by evaluation. On the other hand, history students from both countries consider the evaluation of information as the most important dimension of IL and communication as the second most important. All respondents, regardless of the field of study, assessed competencies associated with searching as less substantial than the two mentioned above, and the competencies connected with processing information as the least important. The ranking of BIM competency dimensions is presented in the table below.

\begin{tabular}{|c|c|c|c|c|c|c|}
\hline \multicolumn{7}{|c|}{$\begin{array}{c}\text { TABLE } 2 \\
\text { Ranking of Competencies Dimensions According to Belief in Importance }\end{array}$} \\
\hline \multicolumn{7}{|c|}{ Belief in Importance } \\
\hline Country & Poland & Spain & Poland & Spain & Poland & Spain \\
\hline BIM Dimension/Field of Study & \multicolumn{2}{|c|}{ Information Science } & \multicolumn{2}{|c|}{ Journalism } & \multicolumn{2}{|c|}{ History } \\
\hline Search & 3 & 3 & 3 & 3 & 3 & 3 \\
\hline Evaluation & 2 & 2 & 2 & 2 & 1 & 1 \\
\hline Processing & 4 & 4 & 4 & 4 & 4 & 4 \\
\hline Communication & 1 & 1 & 1 & 1 & 2 & 2 \\
\hline
\end{tabular}

It seems that students are more focused on the final stages of information processes, which take into account contact with information recipients - readers, information users, patrons. This suggests a user-centered and instrumental approach to the assessment of information competencies.

Analysis of the means of variables shows that Spanish students generally value each dimension higher than Polish students do. The biggest differences might be seen in the dimension of processing-information science students from Spain assessed 7.65 on average while among history students from Poland average score was 6.22. The smallest variation in assessments occurs in the highest-rated area, communication, where the average differences are less than 0.5. Mean values for every field of study are shown in figure 2.

When it comes to the assessment of students' self-efficacy, some interesting phenomena might be observed. According to the competencies' dimensions, the answers of Polish students from different fields of studies created a quite homogeneous ranking (except the fact that history students feel more qualified in evaluating information than students of LIS and journalism, who value more their searching skills). This consistency might be an indicator of the universal character of information literacy teaching at Polish universities across different fields. Also, the ranking of competency dimensions (table 3 ) seems to be slightly different from 


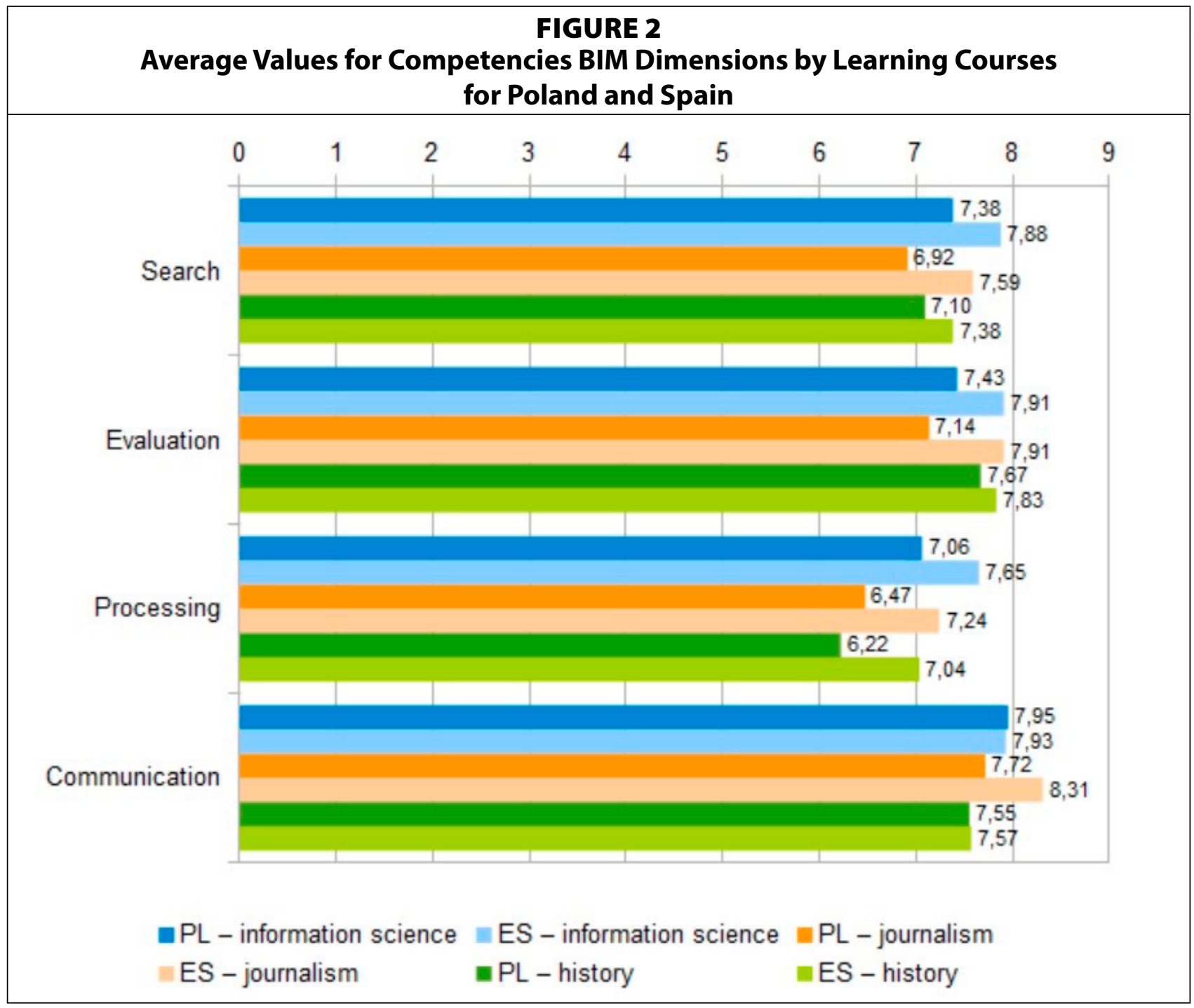

a common attitude of the generation; ${ }^{50}$ on the other hand, they may overestimate their skills, like the others in the countries already studied, ${ }^{51}$ confusing their internet communication or navigation with information retrieval. ${ }^{52}$

In the case of Spain, we see an extremely contrasting situation - the ranking of competencies dimensions varies considerably depending on the field of study. The reasons for this difference require further studies, for example, referring to the academic curricula. It might,

\begin{tabular}{|c|c|c|c|c|c|c|}
\hline \multicolumn{7}{|c|}{$\begin{array}{c}\text { TABLE } 3 \\
\text { Ranking of Competencies Dimension }\end{array}$} \\
\hline \multicolumn{7}{|c|}{ Self-efficacy } \\
\hline Country & Poland & Spain & Poland & Spain & Poland & Spain \\
\hline BIM Dimension/Field of Study & \multicolumn{2}{|c|}{ Information Science } & \multicolumn{2}{|c|}{ Journalism } & \multicolumn{2}{|c|}{ History } \\
\hline Search & 2 & 1 & 2 & 3 & 3 & 2 \\
\hline Evaluation & 3 & 2 & 3 & 2 & 2 & 1 \\
\hline Processing & 4 & 3 & 4 & 4 & 4 & 4 \\
\hline Communication & 1 & 4 & 1 & 1 & 1 & 3 \\
\hline
\end{tabular}


however, reflect a more developed and curriculum-tailored program of teaching IL in Spain, as described in the previous section.

Analysis of the means of variables shows some interesting differences among Spanish students. On average, students of LIS assessed their competences as the most advanced (6.84), students of journalism were only slightly worse $(M=6.73)$, while history students were very critical in assessing their IL level (5.98) - even more than on average all Polish students (6.30). In this context, assessment from students from Poland was more moderate and more consistent. Mean values for every field of study according to dimensions are shown if figure 3.

In the earlier part, we focused on the dimensions of competencies; it is worth deepening reflection and analyzing individual skills. In the Polish study, history students valued mostly the group of information evaluation skills, and information searching as second, which is slightly different from the results of other projects. ${ }^{53} \mathrm{BIM}$ and SE levels concerning operating automated catalogs, the knowledge of the source terminology and typology, and the most relevant authors and institutions within the subject area are rated higher in this group in comparison with other students. They also do not value competencies related to communication and dissemination generally and do not feel skilled in this area.

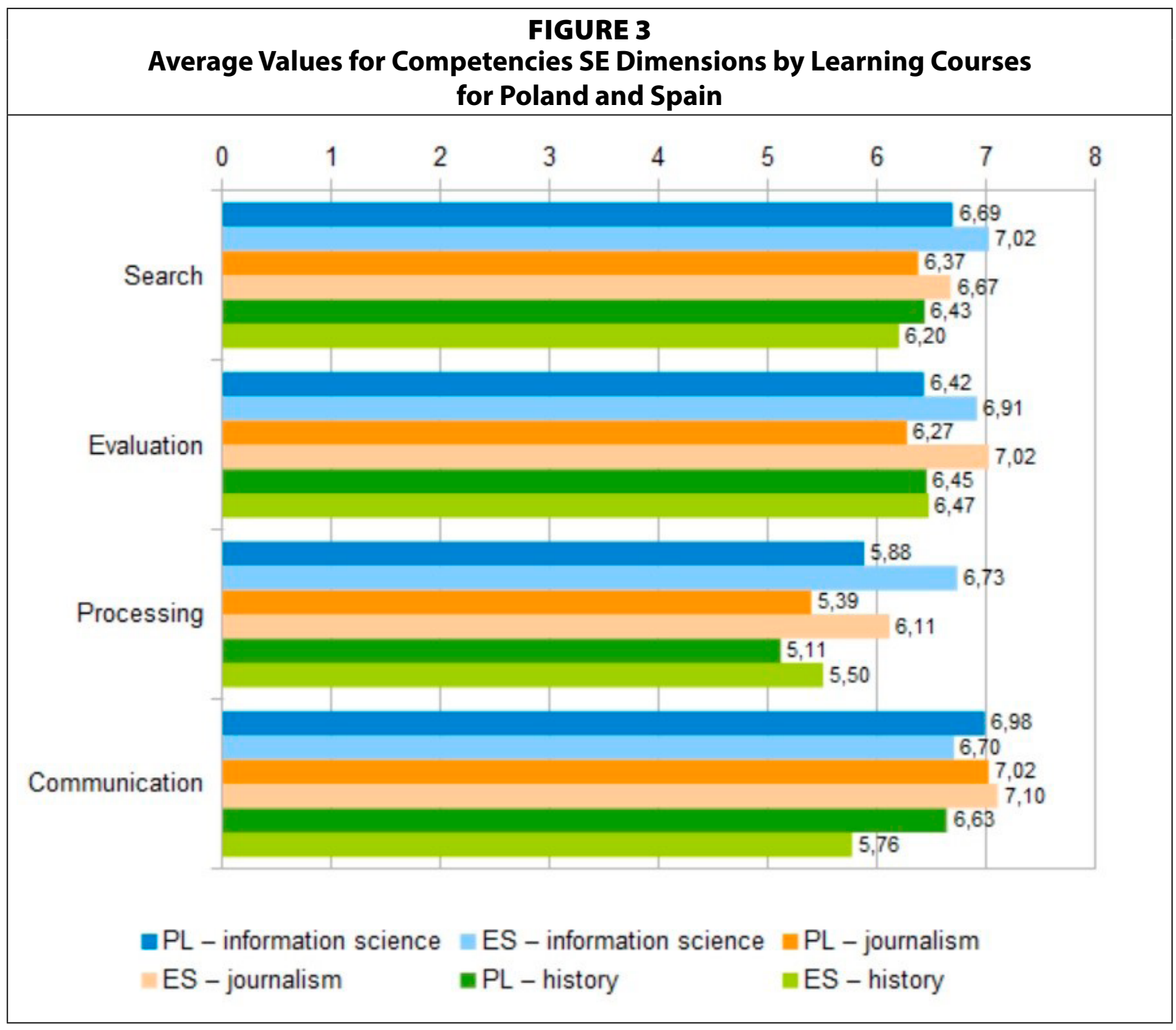


In comparison with the results of the Spanish study, there is only consistency in the negative attitudes (low evaluation of the importance of the ability to employ the ICT tools), but not in the positive ones. The history students in Spain value higher and feel more skilled in abstracting information, writing academic texts (student assignments), recognizing authors' ideas and text structure. They value less the usage of bibliographic reference managers and database managers, as well as installing software. They also feel less skilled in the former two elements, in the knowledge of information search strategies and the laws on information use. ${ }^{54}$

Interestingly, Polish students of journalism think that competencies essential for future historians are completely irrelevant to them, as well as some of the ICT-related skills (statistical software, database managers, installing programs). On the other hand, they perceive themselves as proficient in working with texts (abstracting, structuring text) and using other ICT tools (dedicated to information retrieval on the internet, using spreadsheets, communicating through informal channels, as well as dissemination of information), which is quite different in relation to the Spanish group. They perceive competencies related generally to communication as most important. They also feel most capable in this area. These results seem to confirm those presented in the literature review section. ${ }^{55}$

Polish students of information science are most aware of the advantages of employing specialist tools, evaluating and disseminating information. They have a better understanding of the importance of competency in information retrieval and the impact of the informal communication channels. In spite of their education in this area, they rate printed resources and OPACs or some theoretical issues to be lower. They consider themselves quite skilled in the areas they perceive as important; and, even if they notice some skill deficiencies, their assessment still reaches the medium level compared to the students of other courses.

The analysis of data on LIS students from Spain allowed the authors to identify the principal competencies - they consider them to be important and at the same time highly assess their capabilities. In the area of information searching, these include: using catalogues and electronic sources of secondary information and knowledge about searching strategies. As for the evaluation, the most important are: understanding authors' ideas, knowing the typology of scientific information sources and the most relevant authors and institutions in the subject area. Among the competencies related to information processing, the key points are: using the database and bibliographic reference managers, as well as statistical programs and spreadsheets. The principal competencies in the field of communication are: communicating in other languages, creating written documents and presentations and disseminating information on the Internet. ${ }^{56}$

What seems to be crucial when it comes to creating IL education is a gap between the students belief-of-importance and self-efficacy. Both desired and satisfactory level of competencies seems to be very subjective and contextual. According to the relational model of digital competencies, we do not consider that there is a universal media and information literacy level everyone should achieve. In this model, it is important to take into account a person's lifestyle resulting from gender, age, social background, and so on, their needs at the certain stage of life, and functioning in different areas. ${ }^{57}$

Among the respondents, it was the highest among students of history from Spain, especially when it comes to the dimension of communication. The smallest difference between expectations and the level of self-assessment occurred in the case of Polish students of journalism, especially searching. Generally, students from Spain reported bigger differences be- 
tween their perception of value and their perception of the level of competencies than Polish students. Processing was the dimension, where the gap was the most noticeable (mean value 1.16), followed by communication (1.14), evaluation (1.06), and search (0.81). The means for particular fields of study are presented in figure 4 .

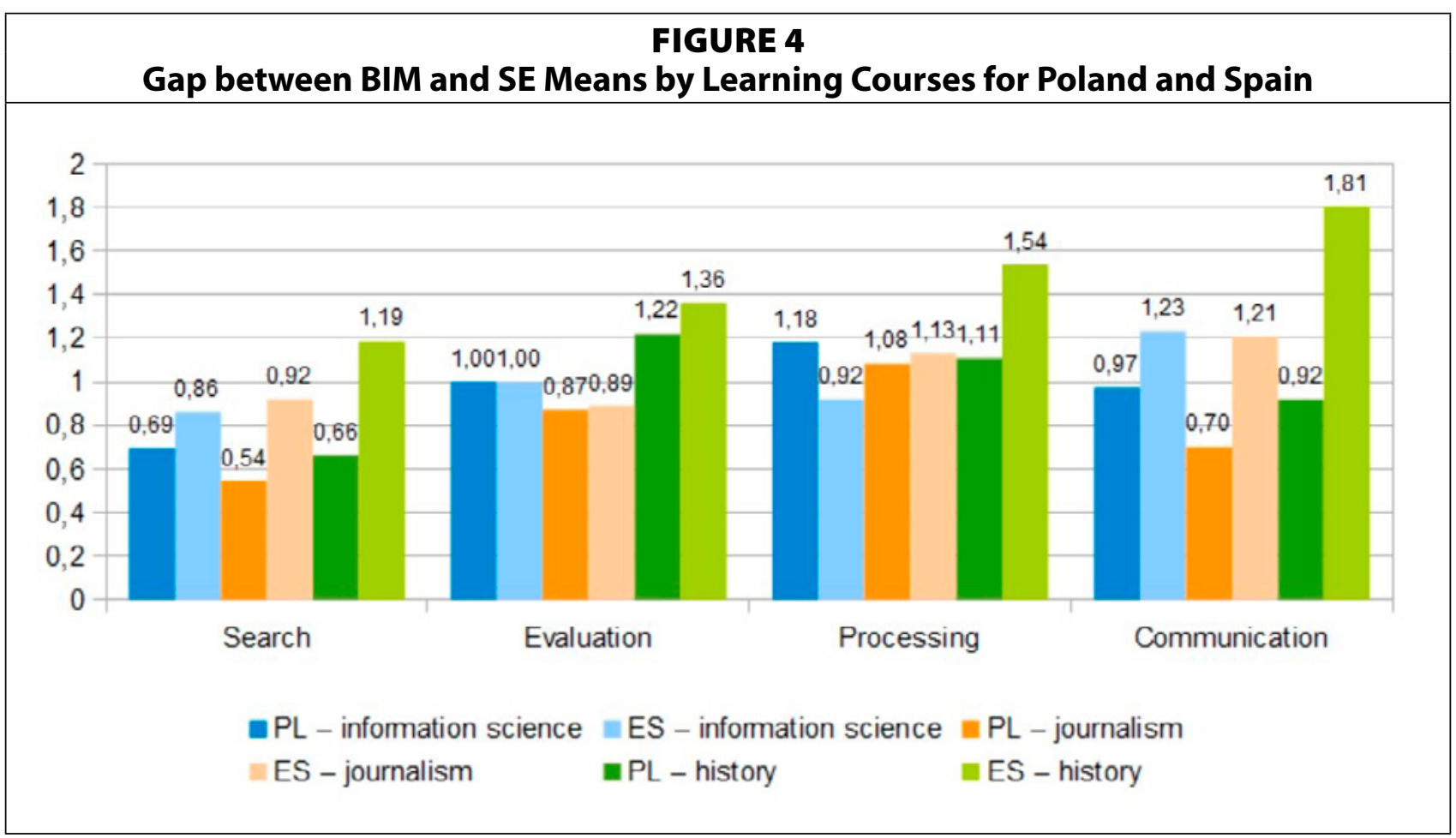

\section{Gender and Level of Study}

Data from Polish universities suggests some differences in BIM-women rate the importance of competency categories higher, and their responses are less diversified according to searching and processing information, as well as communication domain. As for SE, there are no statistically significant differences between men and women. However, regarding particular competencies, men rate their skills in software installation and online information retrieval higher, whereas women rate their skills in the use of printed sources and presentation preparation higher. It does not confirm earlier findings; all the Spanish studies concluded that gender does not differentiate the study group in relation to the assessment of the importance and self-efficacy of IL. A small but statistically significant difference was mentioned only for the whole group of social sciences students in the belief-of-importance aspect. ${ }^{58}$

Polish students - all three groups altogether-show some differences among the levels of studies as well, either in the case of the belief of importance or self-efficacy, in regard to information searching and processing. The older group of doctoral and graduate students values competencies related to the use of ICT higher than BA students, and they assess their skills slightly higher in the use of printed and electronic sources and specialist databases, internet searching, recognizing obsolete materials, evaluation of information resources validity, knowledge about the most relevant authors and institutions of their subject area, typology of scientific sources, and systemizing information. As for the differentiation of Spanish students' competencies according to the level of studies, the results were reported in one article 
only ${ }^{59}$ revealing much higher scores in both BIM and SE for graduates than undergraduates in library and information science course.

\section{Sources of Acquiring Competencies}

Polish respondents, regardless of the course, declared individual learning as their first choice, followed by classes. Self-study as a form of learning seems to be crucially important for graduate students. Feeling more skillful, they are less likely to seek the support of a teacher or librarian. Libraries were not generally mentioned by the respondents as learning sources.

History students are also independent learners, at least in the case of the area of information literacy. ${ }^{60}$ Most of them develop their information skills on their own; classes are the second choice. However, as can be seen from their assessment results, the effects of such learning are not very satisfying (in other words, the skills declared as being learned individually are scored as the worst). However, Spanish students of social sciences (including journalism and information science) declared instruction in the classroom as the main source of their IL skills, ${ }^{61}$ with self-learning mentioned as the second choice, and library as the last one. On the one hand, these preferences can be interpreted by the specifics of LIS curricula, where the students are actually being taught information skills in different courses. On the other hand, however, if lectured effectively, they are expected to know the role and potential of an academic library.

For all surveyed groups, both in Spain and in Poland, the library can be found as the last place where the students learn or improve their information skills. The reasons for that can be different, depending on the academic institution, profile of studies, particular library, or attitude toward libraries among the students in general. Exploring this problem requires further research. Lecturers and librarians should consider potential solutions for modifying their attitudes and/or improving the effects. That includes, for example, courses in self-education and independent learning, developing skills applicable for different types of knowledge and skills to be reached, or encouraging them to benefit IL courses dedicated to particular levels and areas of studies.

Some authors suggest that the problem of overlooking libraries as a source of information competencies results from quite poor relations between libraries and academics. This problem, as well as cases of successful cooperation, has been mentioned in literature. ${ }^{62}$ However, it can be perceived as a challenge for academic librarians to fill the gap proven to exist in students' perception and understanding of a library's role, and educational competencies in particular. This recommendation stays in line with the surveys of IL skills and library usage of $\mathrm{PhD}$ candidates, who declared a need for personal contact with librarians as educators more than limiting library instruction to online training. ${ }^{63}$

The other findings refer both to the content and form of IL training. Differences in attitudes toward IL and skills of this type among students of particular courses can become an inspiration in developing profiled curricula not only in regard to specialist information sources for different disciplines but also IL skills specific to different professions. As discussed above, for example, history students are better in information evaluation, as this is a specific competency of historians working with different types of sources and/or documents. Regarding the potential of an information literacy course, a set of competencies of this category can be enhanced. However, information processing or communication skills, seeming to be less developed in this group, require more attention and improvement. Knowledge of students' IL 
beliefs and self-efficacy should be a fundament of IL curricula dedicated to particular courses. The need to strengthen the belief of the importance of evaluating information sources among LIS students, as well as searching and using information among students of other majors, is recognized. It is also essential to enhance ethical attitudes toward information usage among all students, with the attendees of a journalism course in particular.

As demonstrated in the literature review, close cooperation of academic librarians and faculty is the most effective way of IL training. The current project confirms from the other perspective the need for profiled IL education, strongly related to the course-specific and future professional requirements, and being realized by information professionals.

\section{Conclusions, Limitations, and Future Research}

The results discussed above deepen the knowledge about the information literacy of the students in different countries and make a case for further in-depth comparative studies. Students' IL and education needs are important information to be referred to in curricula design and academic teaching, regarding different requirements and target competencies specific for particular professions and/or areas of activity.

The study has its limitations. Only a part of Polish social and humanistic sciences students was surveyed. The research focused on students of social sciences and humanities. Probably the results of the comparison would be more precise if the research sample had been expanded. It would also be interesting to constantly explore information searching strategies of those who passed a profiled academic IL training.

Either in Spanish or Polish surveys it is explicit, that the students do not perceive libraries as key sources of learning for developing IL competencies. Academic librarians teaching equally with the faculty can be ambassadors of libraries - both as places of learning and/or leisure time and as places, tools, and/or teams effective in information retrieval.

A training program endorsed by empirical research and freely accessible to anyone could provide valuable support to academic learning networks and virtual campus. Therefore, future research should include both further in-depth surveys of students' IL and international comparisons of data in disciplinary and/or national aspects, and the analysis and design of syllabuses including IL content into specific courses. The studies of the effectiveness of profiled IL training seem also to be required, to verify the actual improvement of students' IL and their preparedness to fulfill information tasks in their professional life. 
APPENDIX. The IL-HUMASS Questionnaire

\begin{tabular}{|c|c|c|c|c|}
\hline No. & With Regard to... & $\begin{array}{l}\text { Belief in } \\
\text { Importance }\end{array}$ & Self-efficacy & $\begin{array}{l}\text { Source } \\
\text { of Learning }\end{array}$ \\
\hline & $\begin{array}{l}\text { Information Literacy } \\
\text { Competencies-Abilities }\end{array}$ & $\begin{array}{l}\text { Low High } \\
123456789\end{array}$ & $\begin{array}{l}\text { Low High } \\
123456789\end{array}$ & $\begin{array}{l}\text { Cl Class } \\
\text { Co Courses } \\
\text { S Self-learning } \\
\text { O Others }\end{array}$ \\
\hline \multicolumn{5}{|c|}{ Searching } \\
\hline 1 & $\begin{array}{l}\text { Using print sources of information (books, } \\
\text { papers, and so on) }\end{array}$ & & & \\
\hline 2 & Entering and using OPACs & & & \\
\hline 3 & $\begin{array}{l}\text { Consulting and using electronic sources of } \\
\text { primary information (such as journals) }\end{array}$ & & & \\
\hline 4 & $\begin{array}{l}\text { Using electronic sources of secondary } \\
\text { information (like databases) }\end{array}$ & & & \\
\hline 5 & Knowing the terminology of your subject & & & \\
\hline 6 & $\begin{array}{l}\text { Searching for and retrieving internet information } \\
\text { (such as advanced searches, directories, portals) }\end{array}$ & & & \\
\hline 7 & $\begin{array}{l}\text { Using informal electronic sources of information } \\
\text { (blogs, discussion lists, and the like) }\end{array}$ & & & \\
\hline 8 & $\begin{array}{l}\text { Knowing information search strategies } \\
\text { (descriptors, Boolean operators, and such) }\end{array}$ & & & \\
\hline \multicolumn{5}{|c|}{ Evaluation } \\
\hline 9 & Evaluating the quality of information resources & & & \\
\hline 10 & Recognizing the authors ideas within the text & & & \\
\hline 11 & $\begin{array}{l}\text { Knowing the typology of scientific information } \\
\text { sources (thesis, proceedings, and so on) }\end{array}$ & & & \\
\hline 12 & $\begin{array}{l}\text { Determining whether an information resource is } \\
\text { updated }\end{array}$ & & & \\
\hline 13 & $\begin{array}{l}\text { Knowing the most relevant authors and } \\
\text { institutions within your subject area }\end{array}$ & & & \\
\hline \multicolumn{5}{|c|}{ Processing } \\
\hline 14 & Systematizing and abstract information & & & \\
\hline 15 & Recognizing text structure & & & \\
\hline 16 & $\begin{array}{l}\text { Using database managers (such as Access, } \\
\text { MySQL) }\end{array}$ & & & \\
\hline $18 a$ & Handling spreadsheets (for instance, Excel) & & & \\
\hline $18 \mathrm{~b}$ & Handling statistical programs (for instance, SPSS) & & & \\
\hline 19 & Installing computer programs & & & \\
\hline \multicolumn{5}{|c|}{ Communication-Dissemination } \\
\hline 20 & Communicating in public & & & \\
\hline 21 & Communicating in other languages & & & \\
\hline 22 & $\begin{array}{l}\text { Writing a document (such as a report or an } \\
\text { academic work) }\end{array}$ & & & \\
\hline
\end{tabular}




\begin{tabular}{|l|l|l|l|l|}
\hline 23 & $\begin{array}{l}\text { Knowing the code of ethics in your academic/ } \\
\text { professional field }\end{array}$ & & & \\
\hline 24 & $\begin{array}{l}\text { Knowing the laws on the use of information and } \\
\text { intellectual property }\end{array}$ & & & \\
\hline 25 & $\begin{array}{l}\text { Creating academic presentations (using } \\
\text { PowerPoint, for example) }\end{array}$ & & & \\
\hline 26 & $\begin{array}{l}\text { Disseminating information on the internet } \\
\text { (through webs, blogs, and other social platforms) }\end{array}$ & & & \\
\hline
\end{tabular}

\section{Notes}

1. Maria Pinto, "Information Literacy Perceptions and Behaviour Among History Students," ASLIB Proceedings 64, no. 3 (2012): 304-27; Maria Pinto and Rosaura Fernandez Pascual, "Exploring LIS Students Beliefs in Importance and Self-Efficacy of Core Information Literacy Competencies," College \& Research Libraries 77, no. 6 (2016): 703-26; Maria Pinto et al., "Attitudes toward Information Competency of University Students in Social Sciences," portal: Libraries and the Academy 16, no. 4 (2017): 737-61; Ewa Głowacka, Małgorzata Kisilowska, and Magdalena Paul, "Information Literacy of Polish Students in Social Sciences and Humanities," Zagadnienia Informacji Naukowej 56, no. 1 (2018): 33-51.

2. "Presidential Committee on Information Literacy: Final Report," released on January 10, 1989, www.ala. org/acrl/publications/whitepapers/presidential; Zuzanna Wiorogórska, "Information Literacy and Doctoral Students in France and Poland: A Comparative Study," Zagadnienia Informacji Naukowej 52, no. 1 (2014): 53.

3. Maria Pinto and Dora Sales, "Insights into Translation Students Information Literacy Using the ILHUMASS Survey," Journal of Information Science 36, no. 5 (2010): 619.

4. Albert Bandura, "Self-efficacy: Toward a Unifying Theory of Behavioral Change," Psychological Review 84, no. 2 (1977): 191-215.

5. Albert Bandura, Social Foundations of Thought and Action: A Social Cognitive Theory (Englewood Cliffs, NJ: Prentice-Hall, Inc., 1986).

6. Kristen Zulkosky, "Self-Efficacy: A Concept Analysis," Nursing Forum 4, no. 2 (2009): 95-96.

7. Albert Bandura, "Guide for Constructing Self-efficacy Scales," in Self-efficacy Beliefs of Adolescents, eds. Frank Pajares and Timothy C. Urdan (Charlotte, NC: Information Age Publishing, 2006), 307-37.

8. Alice L. Daugherty and Michael F. Russo, "An Assessment of the Lasting Effects of a Stand-Alone Information Literacy Course: The Students Perspective," Journal of Academic Librarianship 37, no. 4 (2011): 319-26; Margaret Fain, "Assessing Information Literacy Skills Development in First Year Students: A Multi-Year Study," Journal of Academic Librarianship 37, no. 2 (2011): 109-19; Tina Kavšek, Cirila Peklaj, and Urška Žugelj, "Information Literacy Training Evaluation: The Case of First Year Psychology Students," Journal of Academic Librarianship 42 (2016): 293-99.

9. Susan Goodwin and Tina Budzise-Weaver, "Listening to Our Students: Enhancing Library Instruction through a Qualitative Assessment of Student Feedback," Qualitative and Quantitative Methods in Libraries 1 (2012): 51-62; Patricia H. Dawson, Ma Lei Hsieh, and Michael T. Carlin, "Quantitative/Qualitative Analysis of Assessing Student Information Literacy Skills: The Power of Librarian-Faculty Collaborations," Qualitative and Quantitative Methods in Libraries 1, no. 1 (2017): 35-42; Jordan Nielsen and Lora Lennertz Jetton, "Assessing the Effectiveness of Collaborative Subject Specific Library Instruction," Qualitative and Quantitative Methods in Libraries 3, no. 1 (2017): 343-50.

10. Laura Saunders et al., "Information Behaviors and Information Literacy Skills of LIS Students: An International Perspective," Journal of Education for Library and Information Science 56, no. S1 (2015): 80-99.

11. See also: Elaine Blumer, "Information Literacy Competencies of LIS-Students in Switzerland: A Case Study," in Proceedings of the 1st European Conference on Information Literacy (ECIL), Istanbul, Turkey, 22-25 October 2013 (New York, NY: Springer Communications in Computer and Information Science, 2013).

12. Saunders et al., "Information Behaviors and Information Literacy Skills of LIS Students."

13. See: Abby Kasowitz-Scheer and Michael Pasqualoni, "Information Literacy Instruction in Higher Education: Trends and Issues. ERIC Digest" (2002), https://files.eric.ed.gov/fulltext/ED465375.pdf; Boipuso Mologanyi, "Information Literacy from Credit Based to Integrated Information Literacy: A Case of the University of Botswana," Qualitative and Quantitative Methods in Libraries 3, no. 4 (2017): 941-50.

14. Jiři Kratochvil, "Evaluation of e-Learning Course, Information Literacy, for Medical Students," Electronic 
Library 31, no. 1 (2013): 55-69; Jiři Kratochvil, "Efficiency of e-Learning in an Information Literacy Course for Medical Students at the Masaryk University," Electronic Library 32, no. 3 (2014): 322-40.

15. Khalid Mahmood, "Relationship of Students Perceived Information Literacy Skills with Personal and Academic Variables," Libri 63, no. 3 (2013): 232-39.

16. Yu-Hui Chen, "Testing the Impact of an Information Literacy Course: Undergraduates Perceptions and Use of the University Libraries Web Portal," Library \& Information Science Research 37 (2015): 263-74.

17. Beverley Olivier, "Commencing Undergraduates Self-Efficacy and Ability in Finding Academic Resources: Are They Improving?" Studies in Learning, Evaluation, Innovation and Development 5, no. 3 (2008): 1-8; Amy Gustavson and H. Clark Nall, "Freshman Overconfidence in Library Research Skills: A Troubling Relationship?" College \& Undergraduate Libraries 18, no. 4 (2011): 291-306; Melissa Gross and Don Latham, "Undergraduate Perceptions of Information Literacy: Defining, Attaining, and Self-assessing Skills," College \& Research Libraries 70, no. 4 (2009): 336-50; Melissa Gross and Don Latham, "What's Skill Got to Do with It? Information Literacy Skills and Self-views of Ability among First-year College Students," Journal of the American Society for Information Science and Technology 63, no. 3 (2012): 574-83; Mahmood, "Relationship of Students Perceived Information Literacy Skills with Personal and Academic Variables."

18. Gustavson and Nall, "Freshman Overconfidence in Library Research Skills."

19. Russel Michalak and Monica D.T. Rysavy, "Information Literacy in 2015: International Graduate Business Students Perceptions of Information Literacy Skills Compared to Test-Assessed Skills," Journal of Business $\mathcal{E}$ Finance Librarianship 21, no. 2 (2016): 152-74; Russel Michalak, Monica D.T. Rysavy, and Alison Wessel, “Students Perceptions of Their Information Literacy Skills: The Confidence Gap Between Male and Female International Graduate Students," Journal of Academic Librarianship 43 (2017): 100-04.

20. Mahmood, "Relationship of Students Perceived Information Literacy Skills with Personal and Academic Variables"; Sung Un Kim and David Shumaker, "Student, Librarian, and Instructor Perceptions of Information Literacy Instruction and Skills in a First Year Experience Program: Case Study," Journal of Academic Librarianship 41 (2015): 449-56.

21. S. Serap Kurbanoglu, "Self-Efficacy: A Concept Closely Linked to Information Literacy and Lifelong Learning," Journal of Documentation 59, no. 6 (2003): 635-46.

22. Kate Conway, "How Prepared Are Students for Postgraduate Study? A Comparison of the Information Literacy Skills of Commencing Undergraduate and Postgraduate Information Studies Students at Curtin University," Australian Academic \& Research Libraries 42 (2011): 121-35.

23. Jenny Bronstein, "The Role of Perceived Self-Efficacy in the Information Seeking Behavior of Library and Information Science Students," Journal of Academic Librarianship 40 (2014): 101-06.

24. Kim and Shumaker, "Student, Librarian, and Instructor Perceptions of Information Literacy Instruction and Skills in a First Year Experience Program."

25. Gross and Latham, "What's Skill Got to Do with It?"

26. Khalid Mahmood, "Do People Overestimate Their Information Literacy Skills? A Systematic Review of Empirical Evidence on the Dunning-Kruger Effect," Communications in Information Literacy 20, no 2 (2016): 198-213.

27. Alison J. Head and Michael B. Eisenberg, "Project Information Literacy Progress Report: Truth Be Told, University of Washington" (2010): 72, https://www.immagic.com/eLibrary/ARCHIVES/GENERAL/U_WASHUS/ W101101H.pdf.

28. Daugherty and Russo, "An Assessment of the Lasting Effects of a Stand-Alone Information Literacy Course"; Chen, "Testing the Impact of an Information Literacy Course"; Saunders et al., "Information Behaviors and Information Literacy Skills of LIS Students."

29. Fain, "Assessing Information Literacy Skills Development in First Year Students."

30. Christine Bruce, "Faculty-Librarian Partnerships in Australian Higher Education: Critical Dimensions," Reference Services Review 29 (2001): 106-16; Joyce Lindstrom and Diana D. Shonrock, "Faculty-Librarian Collaboration to Achieve Integration of Information Literacy," Reference \& User Services Quarterly 46, no. 1 (2006): 18-23; Lynn D. Lampert, Searching for Respect: Academic Librarians' Role in Curriculum Development (Chicago, IL: Neal-Schuman Publishers, Inc., 2007); Clarence Maybee et al., "It's in the Syllabus: Identifying Information Literacy and Data Information Literacy Opportunities Using a Grounded Theory Approach," Journal of Academic Librarianship 4, no. 4 (2015): 369-76; Barbara Junisbai, M. Sara Lowe, and Natalie Tagge, "A Pragmatic and Flexible Approach to Information Literacy: Findings from a Three-year Study of Faculty-Librarian Collaboration," Journal of Academic Librarianship 42, no. 5 (2016): 604-11; Elizabeth Pickard, "From Barrier to Bridge: Partnering with Teaching Faculty to Facilitate a Multi-term Information Literacy Research Project," Collaborative Librarianship 9, no. 3 (2017): 5.

31. Arthur Sargeant, "Partnerships for Success: Working Together in Higher Education for Student Suc- 
cess," Collaborate: Libraries in Learning Innovation 1 (2016): 1-5.

32. Marianne Kordas and Trina Thompson, "Better Together: A Collaborative Model for Embedded Music Librarianship," Music Reference Services Quarterly 21, no. 1 (2018): 1-11.

33. Janelle Wilkes, Julie Godwin, and Lisa J. Gurney, “Developing Information Literacy and Academic Writing Skills through the Collaborative Design of an Assessment Task for First-year Engineering Students," Australian Academic \& Research Libraries 46, no. 3 (2015): 164-75.

34. Eva Dobozy and Julia Gross, "Pushing Library Information to First-year Students: An Exploratory Study of Faculty/Library Collaboration," Australian Academic \& Research Libraries 41, no. 2 (2010): 90-99.

35. Gloria J. Leckie and Anne Fullerton, "Information Literacy in Science and Engineering Undergraduate Education: Faculty Attitudes and Pedagogical Practices," College of Research Libraries 60 (1999): 9-29.

36. Linda K. Dunn and Xie Shiyi, "Information Literacy Instruction in Canadian Undergraduate Science Education 2000-2015: A Literature Review," Canadian Journal of Information and Library Science 41, no. 4 (2017): 263-84; Michael Mounce, "Working Together: Academic Librarians and Faculty Collaborating to Improve Students Information Literacy Skills: A Literature Review 2000-2009," Reference Librarian 51, no. 4 (2010): 300-20; Bruce E. Massis, "Librarians and Faculty Collaboration: Partners in Student Success," New Library World 113 (2012): 90-93.

37. Junisbai, Lowe, and Tagge, "A Pragmatic and Flexible Approach to Information Literacy."

38. Kate Manuel, Susan E. Beck, and Molly Molloy, "An Ethnographic Study of Attitudes Influencing Faculty Collaboration in Library Instruction," Reference Librarian 43, no. 89/90 (2005): 139-61.

39. Nieves González-Fernández-Villavicencio, María-Isabel Domínguez-Aroca, and Antonio Calderón-Rehecho, "State of the Art of Information Literacy in Spanish University Libraries and a Proposal for the Future," in Worldwide Commonalities and Challenges in Information Literacy Research and Practice, eds. Serap Kurbanoğlu, Esther Grassian, Diane Mizrachi, Ralph Catts, Sonja Špiranec (New York, NY: Springer, 2013), 288-94.

40. Marzena Marcinek et al., "E-learning and B-learning Information Literacy Programs at Science and Technology Universities in Estonia, Finland, Latvia and Poland: A Comparative Study," Proceedings of the IATUL Conferences, Paper 18, http://docs.lib.purdue.edu/iatul/2011/papers/18; Zuza Wiorogórska, "Poland Information Literacy State-of-the-Art Report," https://www.sbp.pl/repository/SBP/sekcje_komisje/komisja_ds_edukacji_informacyjnej/Poland_State_of_the_Art_Report_July2011.pdf [accessed 28 April 2019].

41. Eurostat data presents quite narrow though still complex understanding of digital skills. Methodological information might be found in "A New Comprehensive Digital Skills Indicator," https://ec.europa.eu/digitalsingle-market/en/news/new-comprehensive-digital-skills-indicator [accessed 28 April 2019].

42. Głowacka, Kisilowska, and Paul, “Information Literacy of Polish Students in Social Sciences and Humanities."

43. Pinto, "Information Literacy Perceptions and Behaviour Among History Students"; Pinto et al., "Attitudes toward Information Competency of University Students in Social Sciences"; Pinto and Pascual, "Exploring LIS Students Beliefs in Importance and Self-Efficacy of Core Information Literacy Competencies."

44. In our study, the IL-HUMASS questionnaire was slightly modified (see appendix) so that the respondents understand better the set of competencies, particularly that we have been analyzing the students of different fields of humanities and social sciences, not only those representing LIS. The detailed modifications of the tool included: deletion of the 17th competency (the usage of the bibliographical managers) due to its low popularity among students; dividing the question about the usage skills of spreadsheets and the SPSS statistics software, as the latter is hardly known among students in Poland (18a and 18b); adding the examples of sources and/or software for the improved readability of the tool.

45. Pinto, "Information Literacy Perceptions and Behaviour Among History Students"; Pinto et al., "Attitudes toward Information Competency of University Students in Social Sciences"; Pinto and Pascual, "Exploring LIS Students Beliefs in Importance and Self-Efficacy of Core Information Literacy Competencies."

46. Pinto, "Information Literacy Perceptions and Behaviour Among History Students"; Pinto and Pascual, "Exploring LIS Students Beliefs in Importance and Self-Efficacy of Core Information Literacy Competencies"; Pinto et al., "Attitudes toward Information Competency of University Students in Social Sciences."

47. Pinto et al., "Attitudes toward Information Competency of University Students in Social Sciences," 742.

48 See: Olivier, "Commencing Undergraduates Self-Efficacy and Ability in Finding Academic Resources"; Gustavson and Nall, "Freshman Overconfidence in Library Research Skills"; Mahmood, "Do People Overestimate Their Information Literacy Skills?"

49. Pinto, "Information Literacy Perceptions and Behaviour Among History Students"; Pinto et al., "Attitudes toward Information Competency of University Students in Social Sciences"; Pinto and Pascual, "Exploring LIS Students Beliefs in Importance and Self-Efficacy of Core Information Literacy Competencies"; Głowacka, Kisilowska, and Paul, "Information Literacy of Polish Students in Social Sciences and Humanities." 
50. See: Olivier, "Commencing Undergraduates Self-Efficacy and Ability in Finding Academic Resources"; Gustavson and Nall, "Freshman Overconfidence in Library Research Skills"; Mahmood, "Do People Overestimate Their Information Literacy Skills?"

51. See: Gustavson and Nall, "Freshman Overconfidence in Library Research Skills"; Head and Eisenberg, "Project Information Literacy Progress Report"; Fain, "Assessing Information Literacy Skills Development in First Year Students."

52. See, for example: Olivier, "Commencing Undergraduates Self-Efficacy and Ability in Finding Academic Resources"; Gustavson and Nall, "Freshman Overconfidence in Library Research Skills"; Michalak and Rysavy, "Information Literacy in 2015"; Bronstein, "The Role of Perceived Self-Efficacy in the Information Seeking Behavior of Library and Information Science Students."

53. See: Olivier, "Commencing Undergraduates Self-Efficacy and Ability in Finding Academic Resources"; Gustavson and Nall, "Freshman Overconfidence in Library Research Skills"; Mahmood, "Relationship of Students Perceived Information Literacy Skills with Personal and Academic Variables."

54. Pinto, "Information Literacy Perceptions and Behaviour Among History Students."

55. See, for example: Head and Eisenberg, "Project Information Literacy Progress Report."

56. Pinto, "Information Literacy Perceptions and Behaviour Among History Students," 712-16.

57. Małgorzata Kisilowska, Justyna Jasiewicz, and Anna Mierzecka, "Relationality Is the Key: The Family of Digital Competencies Catalogues and Their Potential Applications," Information Literacy: Key to an Inclusive Society, eds. Serap Kurbanoğlu et al. (New York, NY: Springer, 2016), 294-303; Andrzej Klimczuk et al., "The Framework Catalogue of Digital Competences," MPRA Paper No. 69812, posted 6 March 2016, https://mpra. ub.uni-muenchen.de/69812/.

58. Pinto et al., "Attitudes toward Information Competency of University Students in Social Sciences."

59. Pinto and Pascual, "Exploring LIS Students Beliefs in Importance and Self-Efficacy of Core Information Literacy Competencies."

60. Pinto, "Information Literacy Perceptions and Behaviour Among History Students."

61. Pinto et al., "Attitudes toward Information Competency of University Students in Social Sciences"; Pinto and Pascual, "Exploring LIS Students Beliefs in Importance and Self-Efficacy of Core Information Literacy Competencies."

62. See: Bruce, "Faculty-Librarian Partnerships in Australian Higher Education"; Lindstrom and Shonrock, "Faculty-Librarian Collaboration to Achieve Integration of Information Literacy"; Kratochvil, "Evaluation of e-Learning Course, Information Literacy, for Medical Students" (2013); Kratochvil, "Efficiency of e-Learning in an Information Literacy Course for Medical Students at the Masaryk University" (2014); Junisbai, Lowe, and Tagge, "A Pragmatic and Flexible Approach to Information Literacy"; Pickard, "From Barrier to Bridge."

63. Rachel Fleming-May, and Lisa Yuro, "From Student to Scholar: The Academic Library and Social Sciences PhD Students Transformation," portal: Libraries and the Academy 9, no. 2 (2009): 199-221; Julie Carpenter, "Researchers of Tomorrow: The Research Behaviour of Generation Y Doctoral Students," Information Services and Use 32, no. 1/2 (2012): 3-17; Madden, op. cit. 